\title{
New records of basidiomycetous macrofugi from Kurdistan region - Northern Iraq
}

\author{
Sara Q. Suliaman ${ }^{1 *}$, Talib O. AL- Khesraji ${ }^{2}$ and Abdullah A. Hassan ${ }^{3}$ \\ ${ }^{1}$ Department of Biology, College of Sciences, Tikrit University, Tikrit, Iraq. \\ ${ }^{2}$ Department of Biology, College of Education for Pure Sciences, Tikrit University, Tikrit, Iraq. \\ ${ }^{3}$ Department of Protection, College of Agriculture, Tikrit University, Tikrit, Iraq.
}

Received 7 March, 2017; Accepted 15 April, 2017

\begin{abstract}
This study was carried out within February to June, 2015 to 2016 on macrofungi samples collected from different localities within Iraqi Kurdistan region - Northern Iraq. This mountainous region is rich in forest trees with diverse groups of shrubs and herbs and is expected to support the growth of many macrofungal species. However, this part of Iraq is still unexplored from macrofungal point of view. In this paper seven basidiomycetous macrofungal species from seven genera, six families and two orders : Inocybe flocculosa, Pleurotus nebrodensis, Psathyrella spadiceogrisea, Schizophyllum commune, Volvopluteus gloiocephalus (Agaricales), Lentinus tigrinus and Trametes trogii (Polyporales) were reported from Iraqi Kurdistan. These macrofungal species are recorded for the first time from Iraq.
\end{abstract}

Key words: Macrofungi , Agaricales, Polyporales, Iraqi Kurdistan.

\section{INTRODUCTION}

Macrofungi (or macromycetes) are fungi that produce fruiting bodies visible to naked eye (Mueller et al., 2007). Macrofungi are Basidiomycota or Ascomycota and most of them are saprotrophic or mutualistic (mycorrhizal) but some are plant pathogens (Mueller et al., 2007; Devi and Shrivastava, 2016). Beside their role in ecosystem processes (decomposers of dead wood, bioremediation and biocontrol agents, mycorrhizal organisms), macrofungi serve as food, medicine and producers of pharmaceutical active compounds and many other benefits (Redhead, 1997; De Silva et al., 2013) . Out of 1.5 million species of fungi estimated in the world, only 21,679 macrofungal species (that is, $1.5 \%$ of all known fungal species) have been described (Mueller et al., 2007) .

Kurdistan of Iraq is a mountainous region situated at the northern and north eastern parts of Iraq, varying from some 500 to $800 \mathrm{~m}$ in altitude in the lowest valleys and 2000 to $3600 \mathrm{~m}$ at the summits of the highest ranges (Lahony, 2013).

The Iraqi Kurdistan region $\left(36^{\circ} 11^{\prime} 0^{\prime \prime} \mathrm{N}, 44^{\circ} 0^{\prime} 0^{\prime \prime} \mathrm{E}\right)$ comprises three governorates, Erbil, Suliamaniya and Duhok. It is bordered by Syria to the west, Iran to the east, and Turkey to the north, lying where fertile plains meet the Zagros Mountains. It is traversed by the Sirwan River and the Tigris and its tributaries, the Great Zab and

\section{${ }^{*}$ Corresponding author. E-mail: saraqahtan@yahoo.com.}

Author(s) agree that this article remains permanently open access under the terms of the Creative Commons Attribution License 4.0 International License 
the Little Zab.

Kurdistan of Iraq covers about $40,000 \mathrm{Km}^{2}$ of Iraq. It is with a cold winter (December - March or April) and relatively high rainfall upwards to $800 \mathrm{~mm}$ and the mountains above approximately the $1800 \mathrm{~m}$ level are snowbound for several months and snows often falls in the valleys, while the summer though hot and dry, is comparatively of shorter duration (June to September) than on the other parts of Iraq (May to October). These factors contribute to richer biodiversity situation especially the floral components (Lahony, 2013). Despite its biogeographic importance, Northern Iraq is still unexplored from macrofungal standpoint. However, surveys on macrofungi were reported from some countries bordering Iraq like Turkey (Akata et al., 2014; Güngör et al., 2013; Güngör et al., 2015; Sesli and Denchev, 2008), Iran (Amoopour et al., 2016; Ghobad Nejhad and Kotiranta, 2008; Ghobad-Nejhad and Hallenberg, 2012), Jordan (Saba, 1991) and Saudi Arabia (Abou - Zeid and Altalhi, 2006). This paper deals with seven basidiomycetous macrofungi new to Iraq.

\section{MATERIALS AND METHODS}

Macrofungi samples were collected from different localities within Kurdistan region in the north of Iraq during February to June, 2015 to 2016. These localities are Sami Abdul - Rahman Park $\left(36^{\circ} 11^{\prime}\right.$ $32.6328^{\prime \prime} \mathrm{N} 43^{\circ} 59^{\prime} 7.3356^{\prime \prime} \mathrm{E}$, elevation $394 \mathrm{~m}$ ) and Qandil mountains $\left(36^{\circ} 32^{\prime} 28^{\prime \prime} \mathrm{N} 44^{\circ} 59^{\prime} 46^{\prime \prime} \mathrm{E}\right.$, elevation $\left.3587 \mathrm{~m}\right)$, Erbil district; Chuwarta ( $35^{\circ} 43^{\prime} \mathrm{N} 45^{\circ} 34^{\prime} \mathrm{E}, 20 \mathrm{Km}$ NE Suliamaniya, elevation $1361 \mathrm{~m})$, Dukan lake $\left(36^{\circ} 08^{\prime} \mathrm{N} 44^{\circ} 55^{\prime} \mathrm{E}, 60 \mathrm{~km} \mathrm{NW}\right.$ of Suliamaniya, elevation $515 \mathrm{~m})$ and Tawela $\left(35^{\circ} 12^{\prime} \mathrm{N} 46^{\circ} 10^{\prime} \mathrm{E}\right.$,

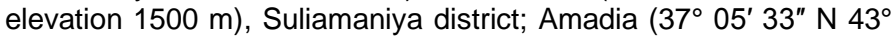
29' 14"E , 70 km N of Duhok, elevation $1202 \mathrm{~m}$ ), Amadia district. Habit (solitary, gregarious or other growth form) and habitat (host or substratum) of the samples with season of fruiting body appearance were recorded and samples were photographed in their natural habitats. Macroscopic features (including features such as cap size, shape, color and surface texture; gills color, attachment to stipe (if present); stipe size, color and surface texture) and microscopic features (including characters like basidia size and their spore number, spore shape, size and color and presence or absence of cystidia and their shapes and types) of macrofungi were reported. Cotton blue in lactophenol was used for light microscopy. Macrofungi were identified according to literatures, keys and monographs (Gargano et al., 2011; Justo et al., 2011; Kuo, 2003; Kuo, 2011; Laursen et al., 2013; Phillips, 2013; Ryvarden and Gilbertson, 1993; Senthilarasu, 2015; Watanabe, 2010). All samples were deposited in Biology Department, College of Sciences, Tikrit University.

\section{RESULTS AND DISCUSSION}

During the survey of different localities of Iraqi Kurdistan region, Northern Iraq, seven basidiomycetous macrofungal species, Inocybe flocculosa, Pleurotus nebrodensis, Psathyrella spadiceogrisea, Schizophyllum commune, Volvopluteus gloiocehalus (Agaricales), Lentinus tigrinus and Trametes trogii (Polyporales) were reported. These fungi are reported for the first time from
Iraq. Their description and distribution are given as follows:

Kingdom: Fungi

Subkingdom: Dikarya

Phylum: Basidiomycota

Subphylum: Agaricomycotina

Class: Agaricomycetes

Subclass: Agaricomycetidae

Order: Agaricales

Family: Inocybaceae

Species: Inocybe flocculosa (Berk) Sacc.

Fruiting body: Cap 20 to $25 \mathrm{~mm}$ broad, tiny, fibrous, bell or convex with light umbonate, pale brown, surface tomentose to squamose appear lighter than the ground color; gills attached to the stipe, pale brown, crowded; stipe 40 to $60 \mathrm{~mm}$ long, 3.0 to $3.8 \mathrm{~mm}$ wide, cylindrical, surface cream colored, pruinose, solid, bent at the bulbose base, central; ring and volva absent (Figure 1). Microscopic feature: Basidium 20 - $25 \times 6.25$ - $7.5 \mu \mathrm{m}, 4$ spored, spores $8.0-11.25 \times 5.5-6.5 \mu \mathrm{m}$, almond, smooth, light brown color; cheilocystidia and pleurocystidia similar $90.6-112.0 \times 20-25 \mu \mathrm{m}$, hyaline, fusiform, apically with light brown crystals (Figure 2).

Gregarious among leaf litter in mixed forest of Quercus spp. and other tree species in Chuwarta, Suliamanyia district, inedible, March to April. Inocybe flocculosa was reported from Japan (Kobayashi and Courtecuisse, 1993), India (Cimap, 2005) and Turkey (Sesli and Denchev, 2008; Solak et al., 2009). Reports are not available on this species from Iran and Arab countries bordering Iraq.

Order: Agaricales

Family: Pleurotaceae

Species: Pleurotus nebrodensis ( Inzenga ) Quel.

Fruiting body: cap 38 to $142 \mathrm{~mm}$ broad , 60 to $110 \mathrm{~mm}$ high, fleshy, initially hemispherical to convex with inrolled margin, then flattens and finally depressed at centre with uplifted wavy margin, smooth, cracking a part at maturity; gills decurrent, whitish at first then turn white yellowish or creamy or light brown, crowded, edges smooth; stipe 35 to $83 \mathrm{~mm}$ long, 17 to $38 \mathrm{~mm}$ wide, cream or whitish, central or excentric, unequal cylindrical, often bent, surface with longitudinal grooves, solid; ring and volva absent (Figure 3). Microscopic features: Basidium $45-55$ $\times 8-10 \mu \mathrm{m}, 4$ - spored, spores $9.0-12.5 \times 5.0-7.5 \mu \mathrm{m}$, hyaline, cylindrical, smooth; cheilocystidia abundant 45 $50 \times 7.5-9.0 \mu \mathrm{m}$, granular capitate (Figure 4).

Solitary or gregarious on plants debris, edible, Haw Mountain, Amadia district and Qandil Mountain, Erbil district, April to May. Pleurotus nebrodensis was reported from Turkey (Sesli and Denchev, 2008) and other countries like Spain (De Román and Boa, 2004) and Italy (Venturella et al., 2002). This species was declared by IUCN as critically endangered species in 2006 

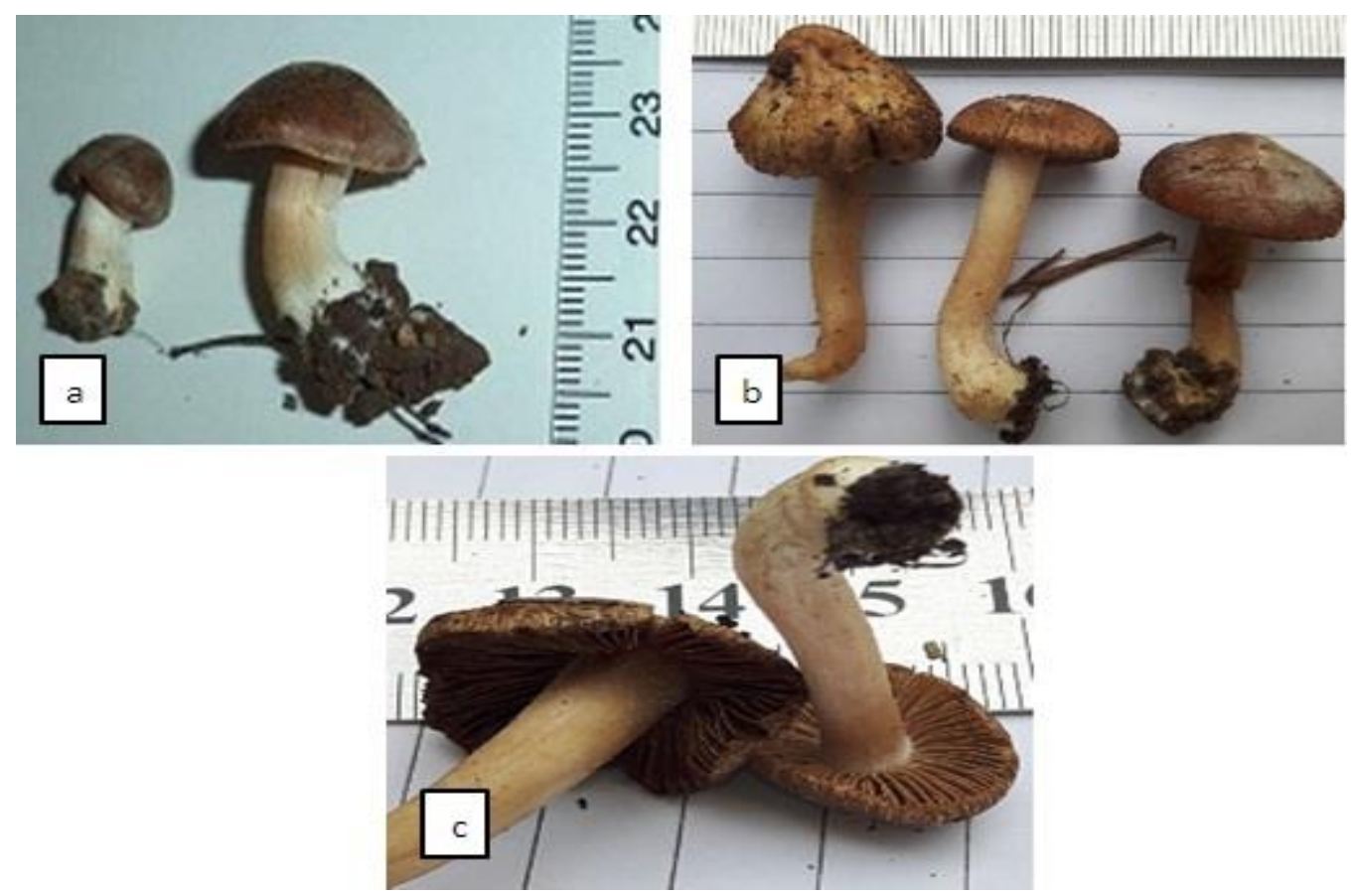

Figure 1. Inocybe flocculosa. a - c: fruiting body.
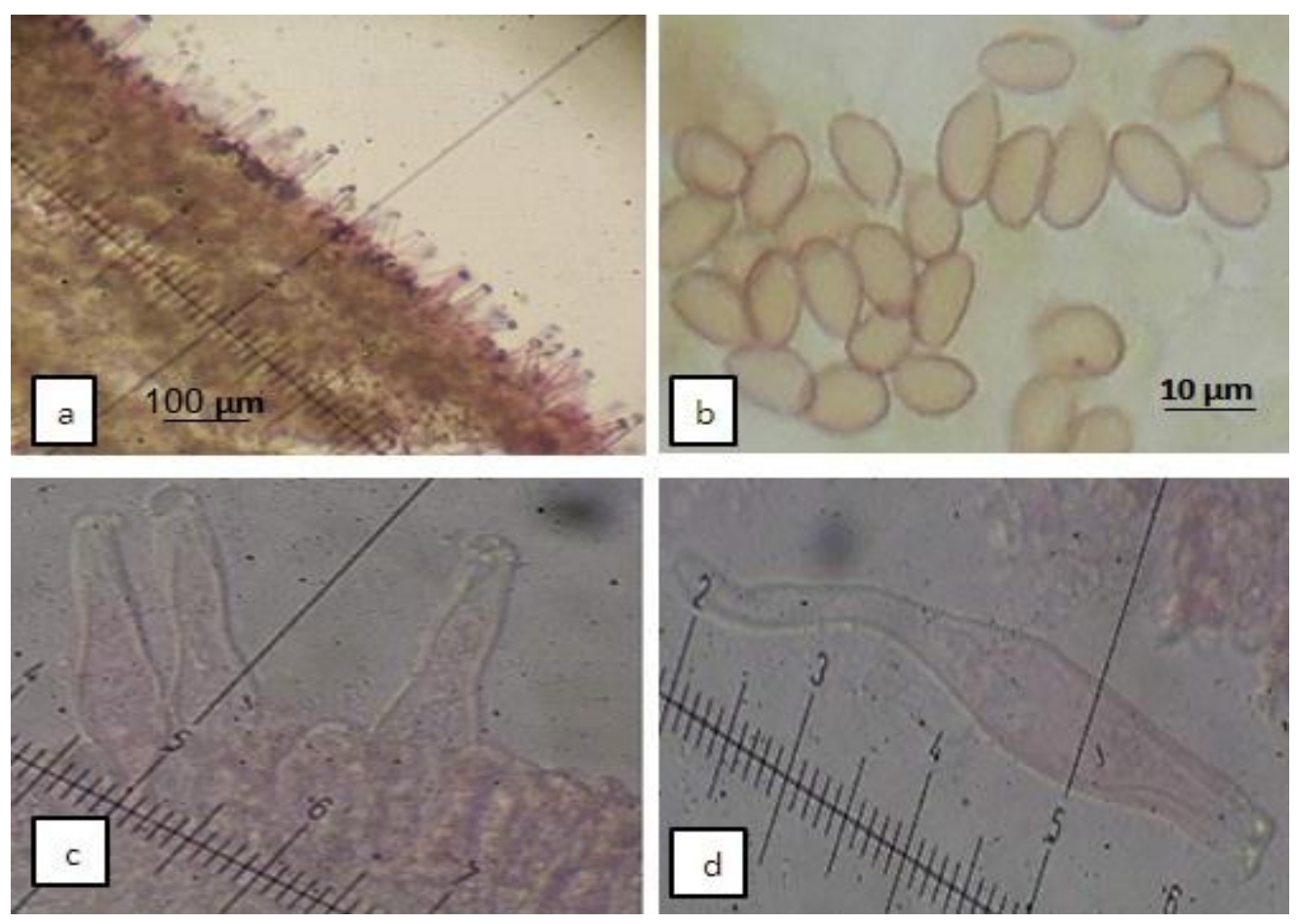

Figure 2. Inocybe flocculosa. a, hymenium; b, spores; c, d, cystidia (1 line $=2.5 \mu \mathrm{m}$ ).

(Venturella, 2006).

Order: Agaricales

Family: Psathyrellaceae
Species: Psathyrella spadiceogrisea (Schaeff.) Maire. Fruiting body: Cap 10 to $30 \mathrm{~mm}$ broad, 5 to $10 \mathrm{~mm}$ high, somewhat fleshy, conical or convex, smooth, medium brown; gills attached to the stipe, dark brown; stipe 10 to 

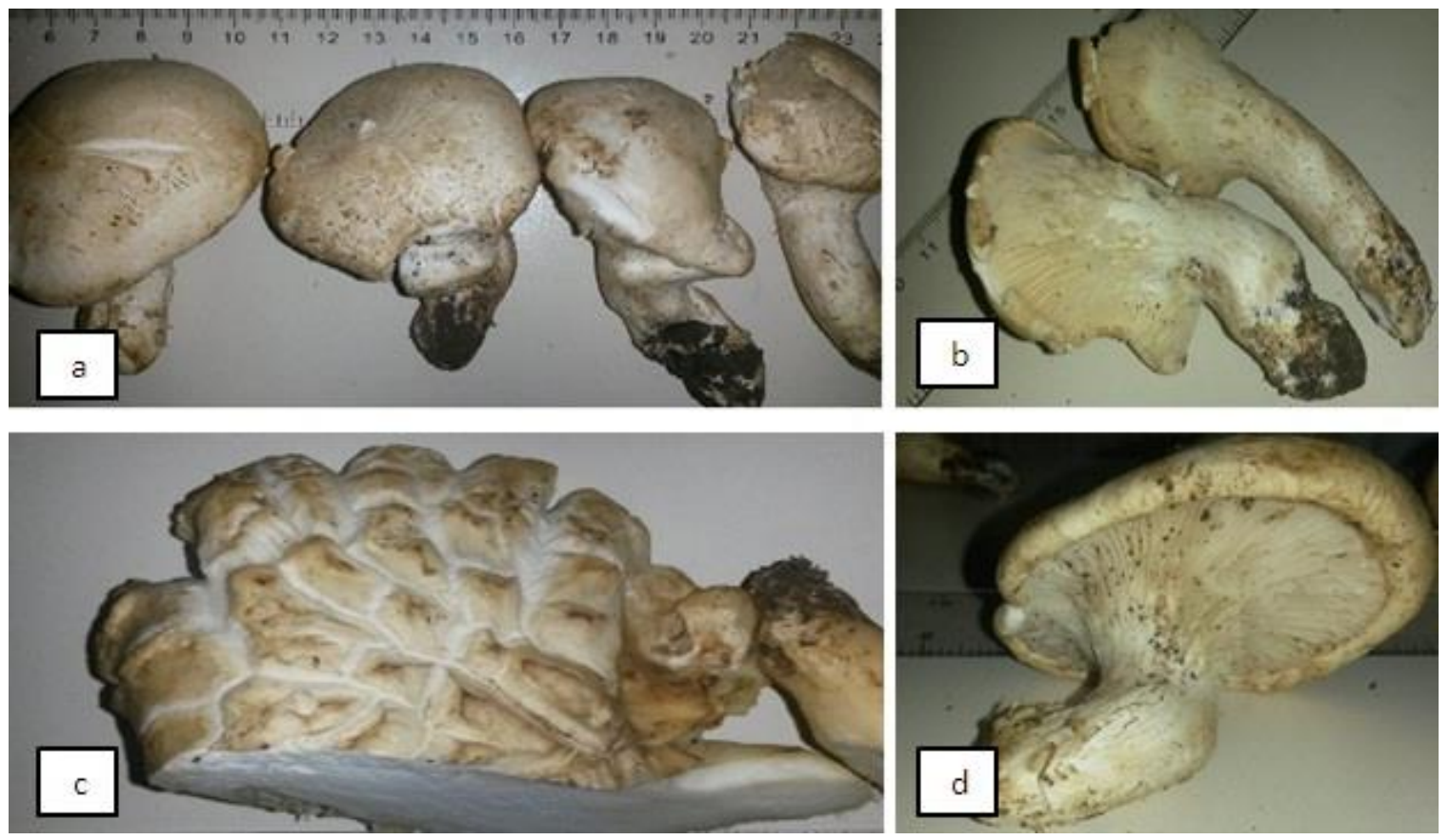

Figure 3. Pleurotus nebrodensis. a - d, fruiting body. Note the bent stipe in $\mathrm{d}$.
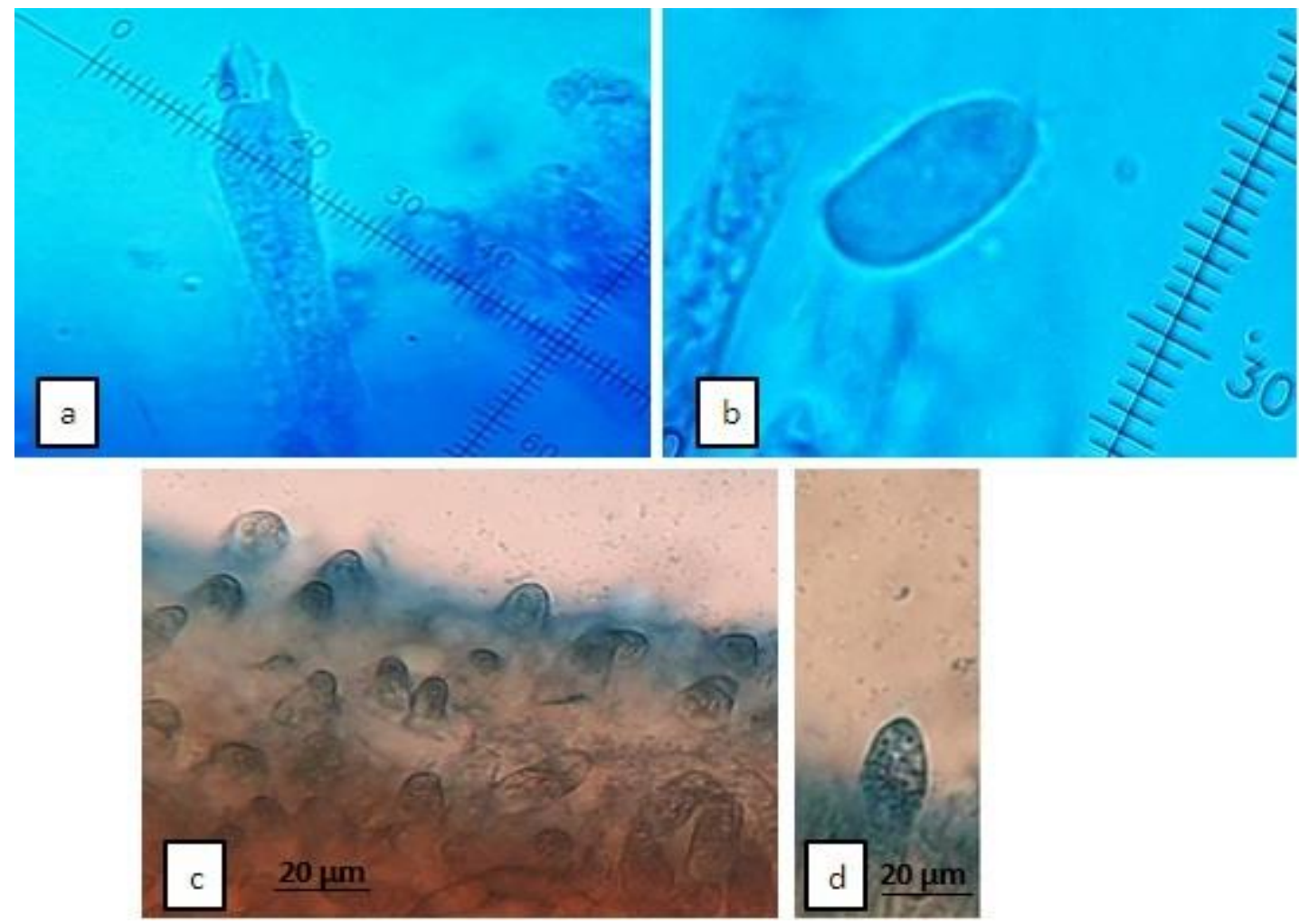

Figure 4. $P$. nebrodensis. $a$, basidium; b, spore; c, cheilocystidia - surface view; $d$, granular capitates cystidia . a, c, d: 1 line $=2 \mu \mathrm{m}$.

$50 \mathrm{~mm}$ long, 10 to $12 \mathrm{~mm}$ wide, unequal cylindrical, central, hollow, whitish, appear dark brown at the upper part near the cap, without ring and volva (Figure 5).

Microscopic features: Basidium $20-25 \times 10-12 \mu \mathrm{m}, 4$ 

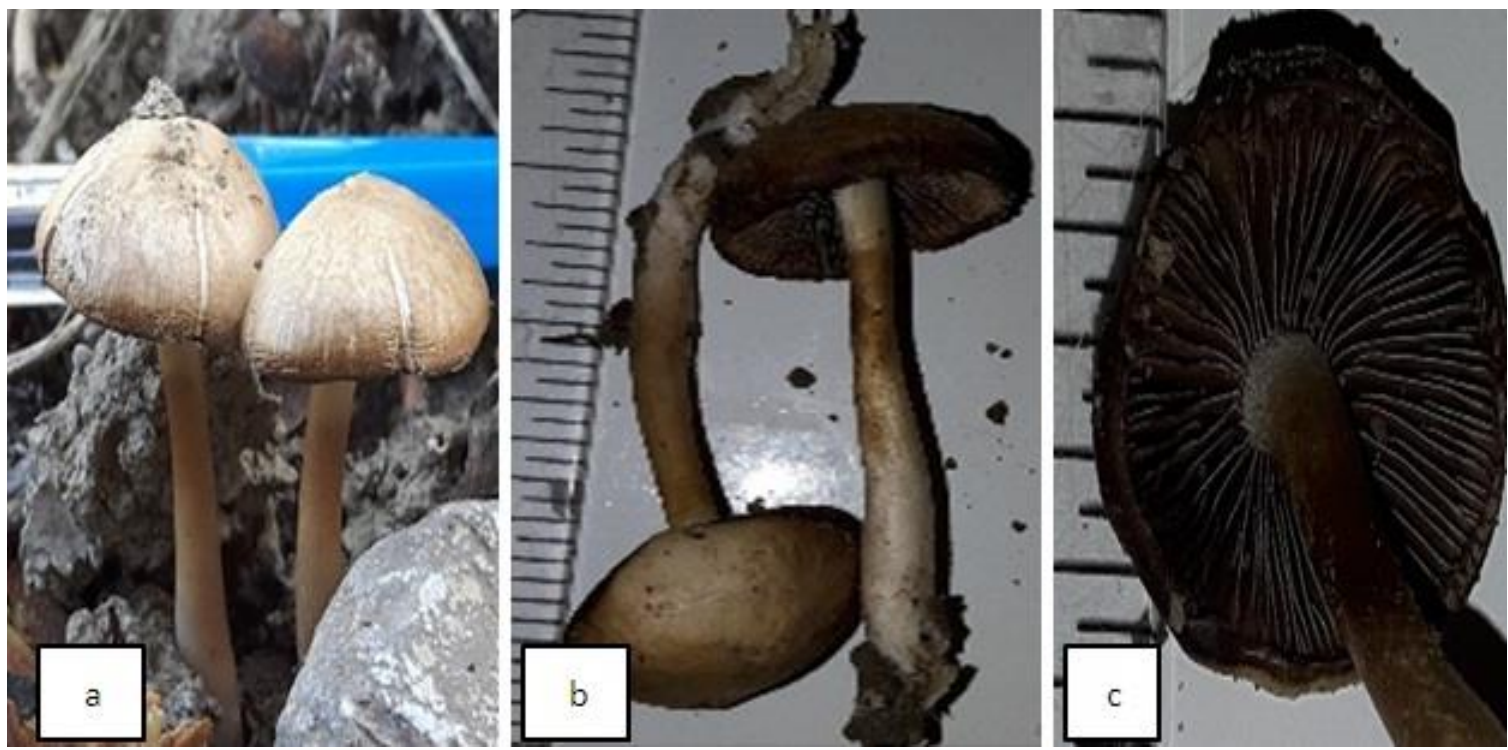

Figure 5. Psathyrella spadiceogrisea. a, fruiting body in natural habitat; b, unequal cylindrical stipe; c, gills - stipe attachment.
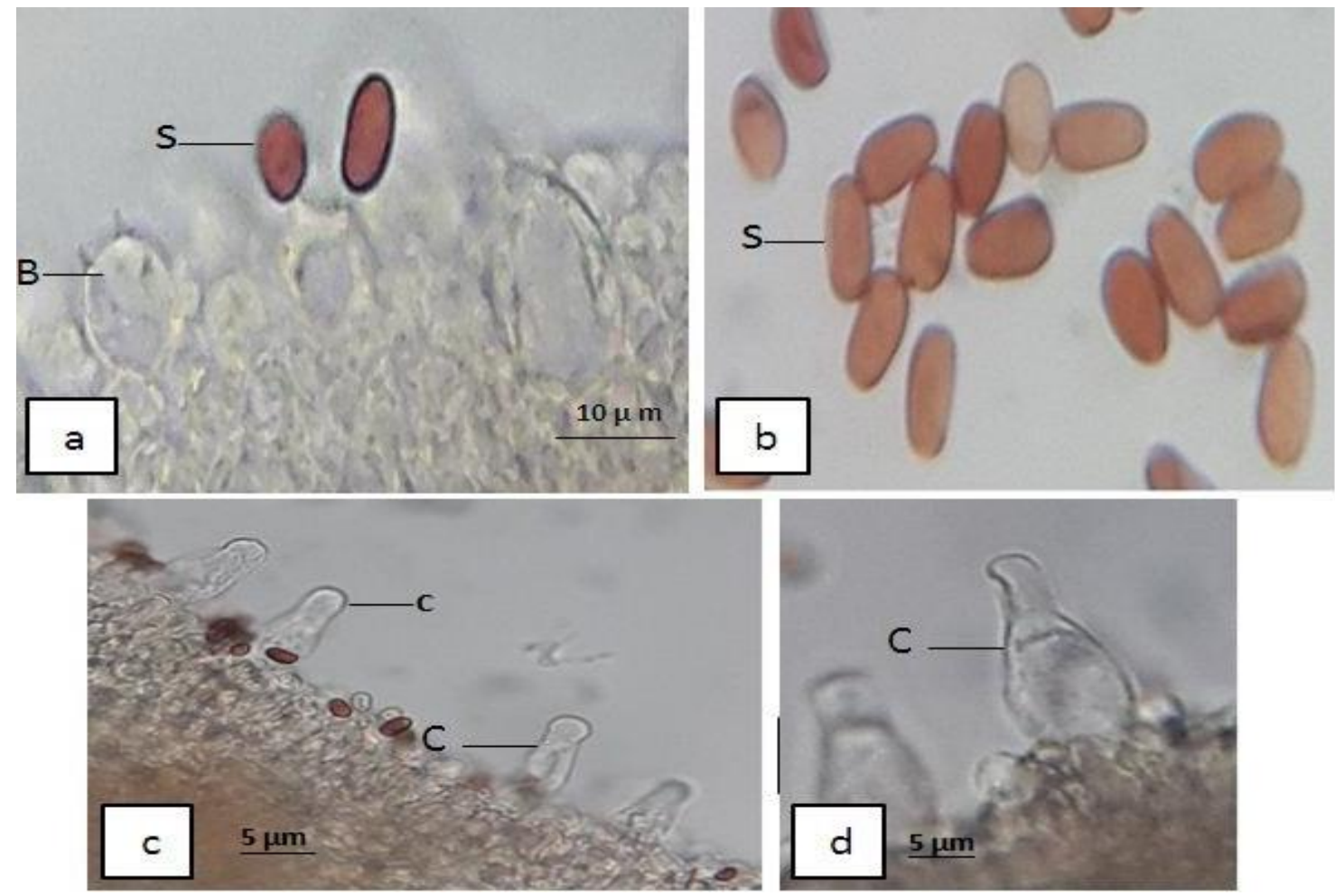

Figure 6. P. spadiceogrisea. a, basidium (B) and spores (S); b, spores; c, pleurocystidia - surface view ; d, utriform pleurocystidia (C).

- spored, spores 7 - $10 \times 4.0-6.5 \mu \mathrm{m}$, elliptical with pore, smooth, deep brown; pleurocystidia clavate and utriform to about $50.0 \times 12.5 \mu \mathrm{m}$; cheilocystidia similar to utriform pleurocystidia (Figure 6) .
Solitary or gregarious on trunks of dead grape (Vitis vinifera) trees, inedible, Dukan Lake, Sulaimaniya district, February to March. This fungal species was reported from Italy (Perini et al., 1999), Austria (Pidlich - Aigner et 

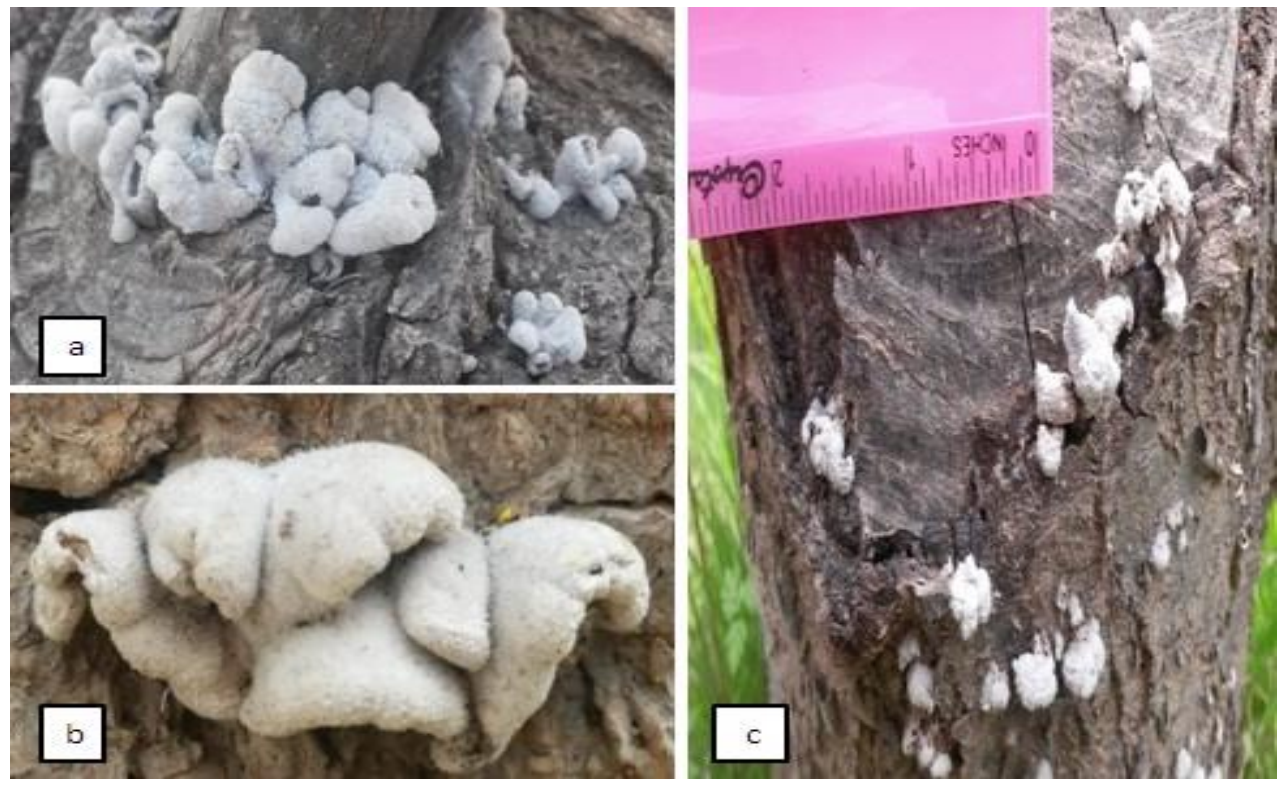

Figure 7. Schizophyllum commune. a, b, fruiting body in natural habitat; c, fruiting body on burned trunk.
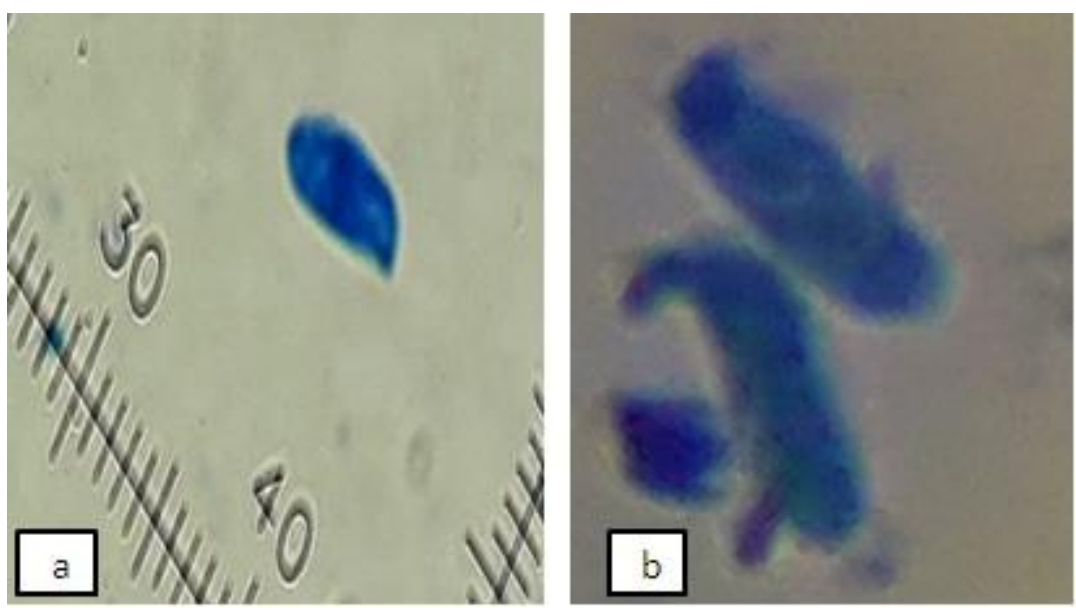

Figure 8. S. commune. a, spore; b, spores magnified . 1 Line $=1 \mu \mathrm{m}$.

al., 2001), Czech Republic and Slovakia (Vašutová, 2006), Nordic countries (Larsson and Örstadius, 2008), Turkey (Doğan et al., 2007; Sesli and Denchev, 2008) and Cameron (Kinge et al., 2013).

\section{Order: Agaricales}

Family: Schizophyllaceae

Species: Schizophyllum commune Fries

Fruiting body: Cap 10 to $50 \mathrm{~mm}$ broad, tiny, sessile or on short stem, fan shaped or shell shaped, irregular, depending on where it attached to the trunk, white to light grayish or tan, upper surface covered with dense hairs; gills grayish, narrow, diffuse from the attachment point, split longitudinally and they curl back to protect the hymenium during dry weather (Figure 7). Microscopic features: basidium 4 - spored; spores 5.5 - $7.0 \times 0.9$ - 3.0 $\mu \mathrm{m}$, cylindrical, curved in one end, smooth, hyaline; clamp connections present; cystidia absent (Figure 8).

Overlapping or gregariously on dead or living Prunus domestica and P. armeniaca trees, edible, Dukan Lake, Sulaimaniya district, March to April. Schizophyllum commune was reported from Turkey (Afyon et al., 2005; Sesli and Denchev, 2008), Iran (Ghobad-Nejhad and Wallenberg, 2012) and other countries like Brazil (Groposo and Loguercio, 2005). 

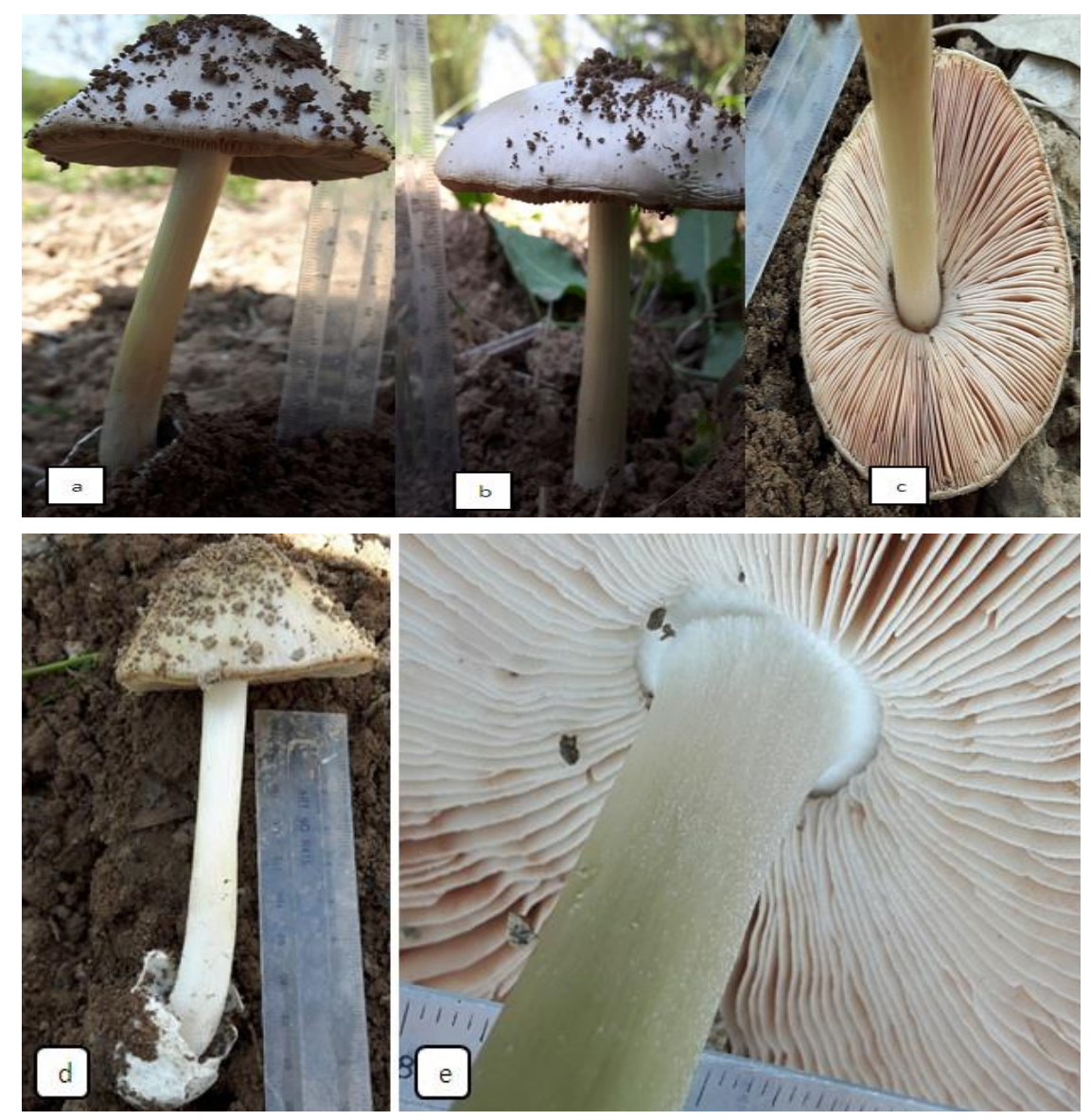

Figure 9. Volvopluteus gloiocephalus. a, b, fruiting body in natural habitat with bell shaped cap in a and convex cap in b; c, croweded gills; $d$, stipe with volva ; e, stipe with white granules.

Order: Agaricales

Family: Pluteaceae

Species: Volvopluteus gloiocephalus (DC.) Vizzini, Contu \& Justo

Fruiting body: Cap 76 to $90 \mathrm{~mm}$ broad, fleshy, bell shaped at early stage becoming convex or flat in age with umbonate, radialy streaked with apprised pale grayish fibrils, smooth, shiny, whitish to creamy; gills free from the stipe, broad, thick, crowded and have a pink color; stipe 124 to $129 \mathrm{~mm}$ long, 10 to $12 \mathrm{~mm}$ wide, solid, easy to separate from the cap, cylindrical tapering slightly to top, pruinose, ring absent; volva: 21 to $25 \mathrm{~mm}$ long, membranous, sac - like (Figure 9). Microscopic features: Basidium 22.5 - $40.0 \times 10.0$ - $12.5 \mu \mathrm{m}, 4$ - spored; spores $10.0-17.5 \times 8.0-11.25 \mu \mathrm{m}$, elliptical with smooth wall , pinkish brown color; both pleurocystidia (50 - $75 \times 10$ 15) $\mu \mathrm{m}$ and cheilocystidia clavate; clamp connections absent (Figure 10).

Solitary, scattered on soil, edible, Sami Abdul Rahman Park, Erbil district, March to April. Volvopluteus gloiocephalus was reported from Turkey (Atila and Kaya, 2008; Kaya, 2015) and Iran (Fadavi and Abbasi, 2015).
Order: Polyporales

Family: Polyporaceae

Species: Lentinus tigrinus (Bull.) Fr.

Fruiting body: Cap 42 to $140 \mathrm{~mm}$ broad, fleshy, convex at early stage with blackish brown then becoming funnel shaped and white yellowish color with a somewhat wavy margin, upper surface covered with dense blackish brown hairs or scales which become scattered and crowded over the center in age; gills - like decurrent, white to yellowish white, crowded, toothed; stipe 48 to $62 \mathrm{~mm}$ long, 6 to $12 \mathrm{~mm}$ wide, yellowish white, centric, cylindrical, attenuate downwards into blackish root - like extension, covered with blackish brown hairy scales, dark at the base, often bent, hollow; ring and volva absent (Figure 11) . Microscopic features: basidium $18-20 \times 4.5$ - $5.0 \mu \mathrm{m}, 4$ - spored; spores $6.25-10.0 \times 2.5-3.75 \mu \mathrm{m}$, narrow cylindrical or fusiform, hyaline, smooth; clamp connections present; cystidia absent (Figure 12).

Gregarious on dead Pistacia atlantica trees (Habbat Khadra in Arabic, Qazwan in Kurdish), localy edible, Haw mountain, Amadia, Amadia district, April to June. This 

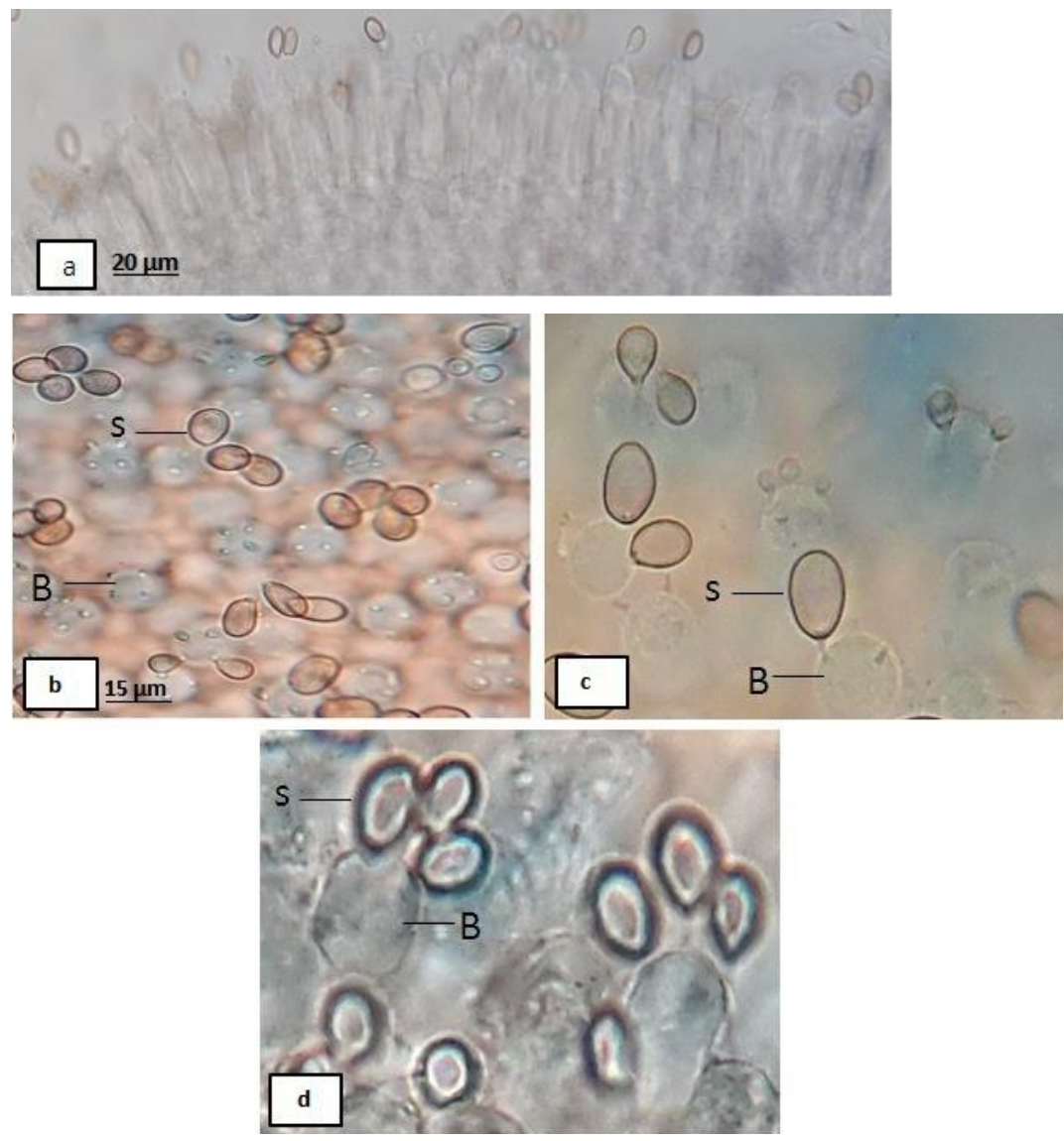

Figure 10. V. gloiocephalus. a, hymenium; b, basidia (B) and spores (S) surface view; c, d, basidia and spores magnified.
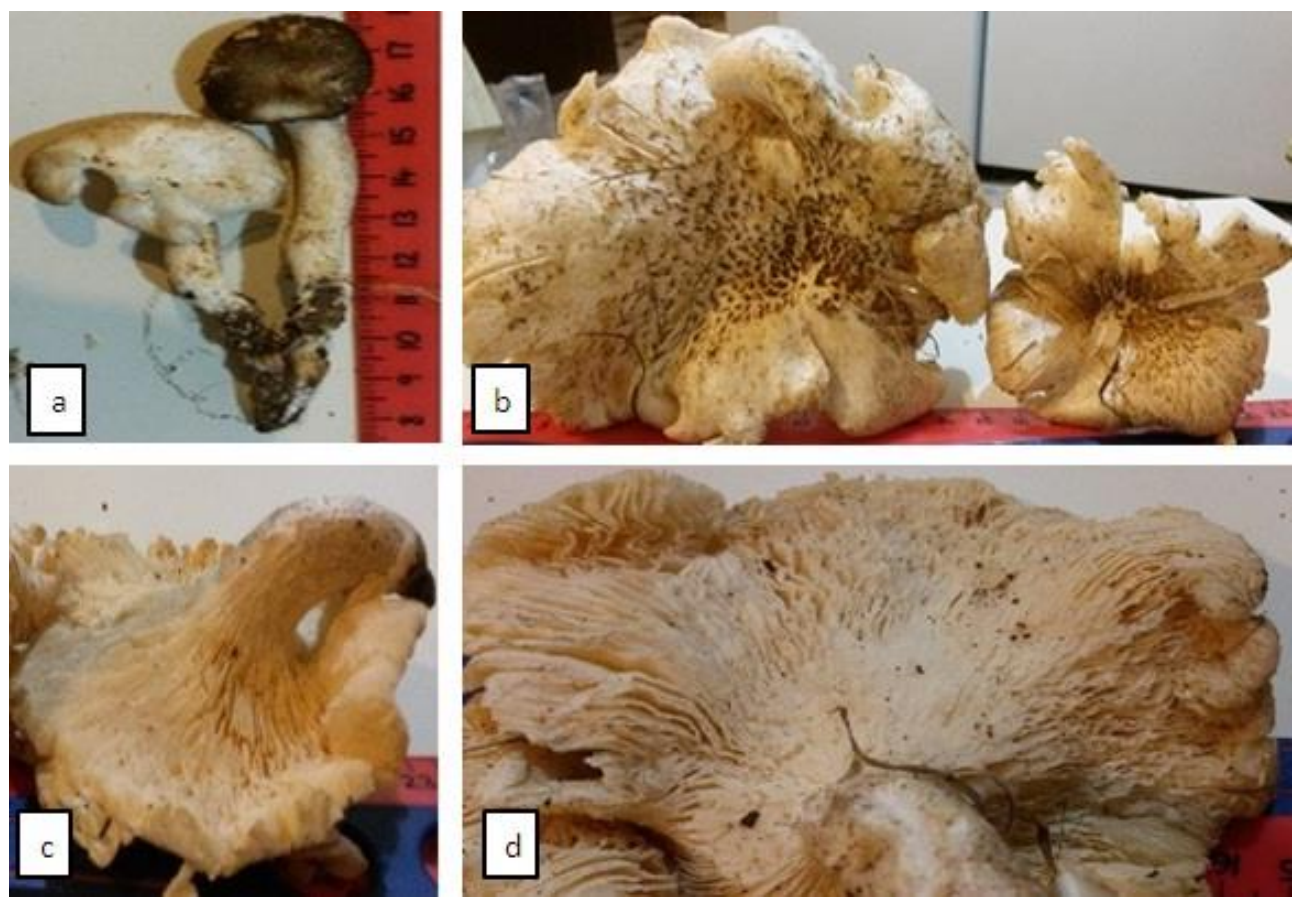

Figure 11. Lentinus tigrinus. a, young fruiting body with blackish cap; b, cap upper surface covered with blackish brown hairs; crowded hairs over cap center; c, hairs on the stipe; $d$, toothed gills . 

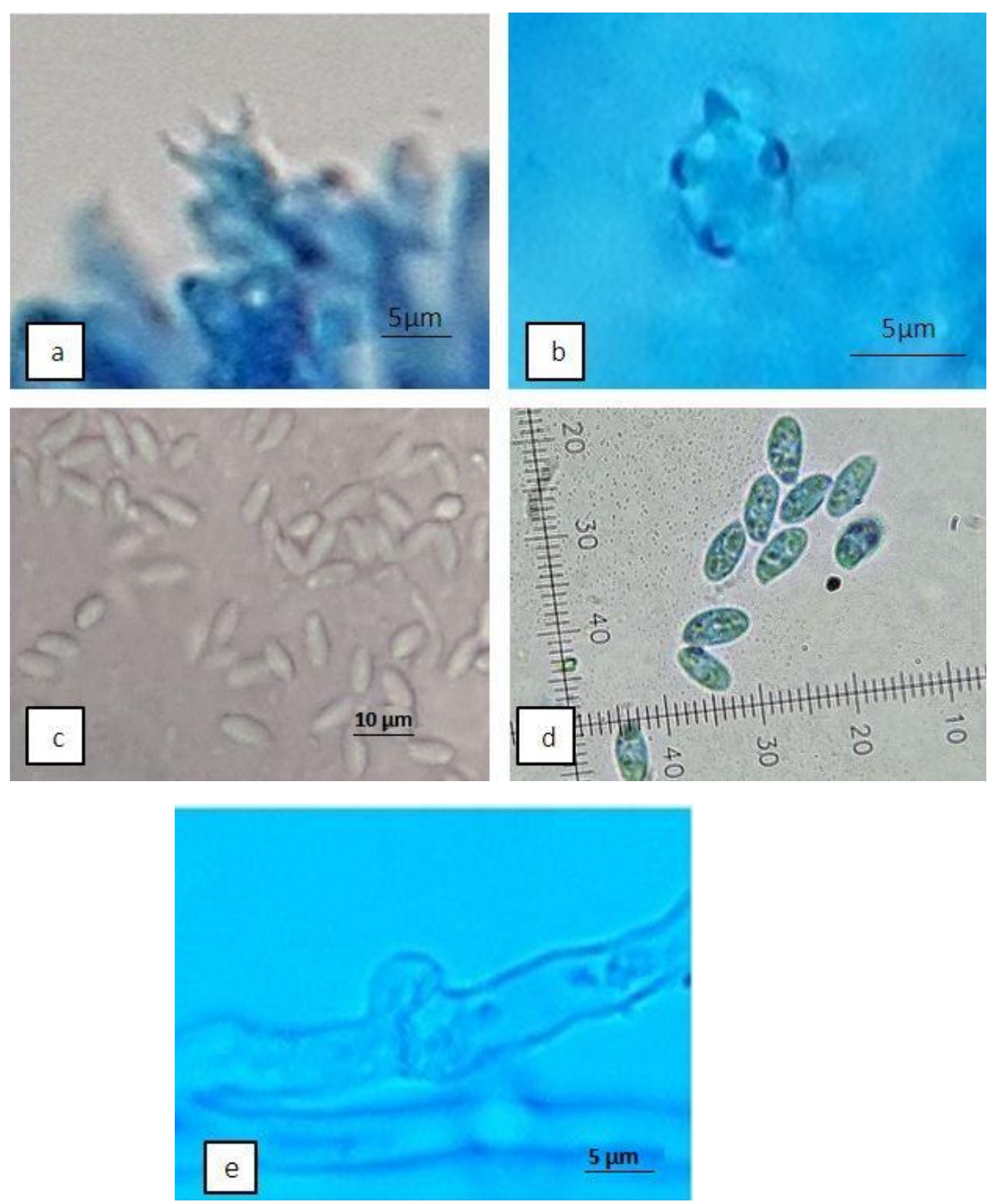

Figure 12. L. tigrinus. a, basidium in section; $b$, basidium in surface view with four sterigmata; c, spores unstained; $d$, spores stained ; e, clamp connection.

fungus was reported from Turkey (Sesli and Denchev, 2008), south western Nigeria (Adejumo and Awosanya, 2005), Thailand (Karunarathnas et al., 2011), Philippine (Dulay et al., 2014; Dulay et al., 2012), Pakistan (Razaq and Shahzad, 2015) and India (Senthilarasu, 2015; Sharma and Atri, 2015).

\section{Order: Polyporales}

Family: Polyporaceae

Species: Trametes trogii Berk.

Fruiting body: Cap 46 to $163 \mathrm{~mm}$ long, sessile, effused or resupinate, snowy white or cottony colored flesh. In maturity, the color turns to cream - buff or brown - buff, the upper surface covered with roughen brown hairs and the texture of the fungus becomes tough and wooden in age and shows the surface of the cap divided into zonate and sharp edges, flesh brown, continuous with tubular layer and characterized by the inability to separate the tubes from each other and ends at apex with circular brown pores (Figure 13). Microscopic features: Basidium $19-22 \times 5.5-7.5 \mu \mathrm{m}$ wide, 4 - spored, spores 10.0 $12.5 \times 2.5-5.0 \mu \mathrm{m}$, cylindrical, hyaline; hyphal system, trimitic, generative hyphae with clamp connections, skeletal hyphae with non - septate and binding hyphae that is frequently branching; cystidia absent (Figure 14).

Gregarious to cluster on soil in orchards and on dead Populus trees, inedible, Amadia, Amadia district, April to June. Trametes trogii was reported from Turkey (Sesli and Denchev, 2008) and warmer parts of Europe (Ryvarden and Gilbertson, 1993).

\section{Conclusion}

It is concluded that the vegetation and climatic conditions make Iraqi Kurdistan an ideal place for growth and development of macrofungi. This region is still unexplored 

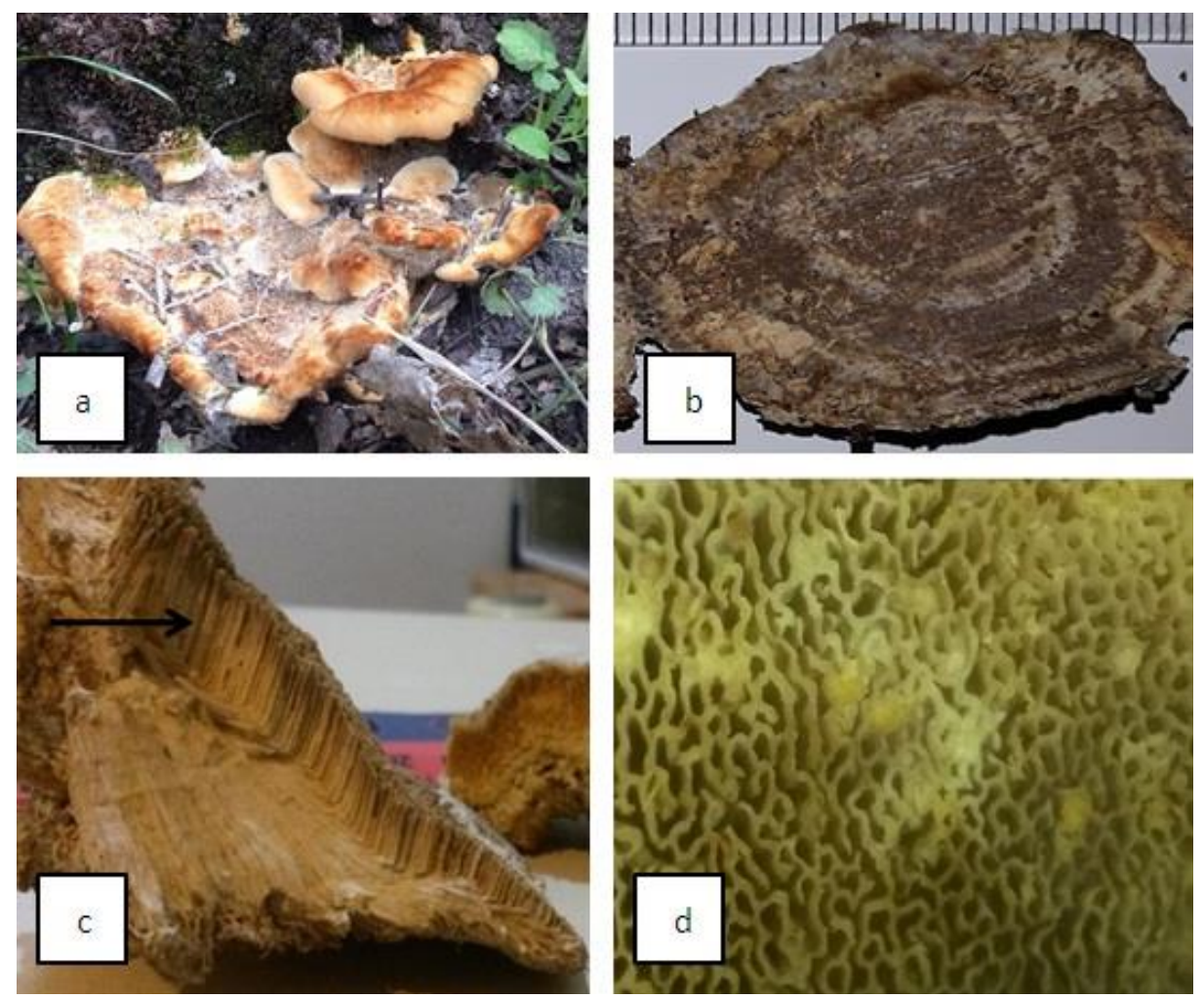

Figure 13. Trametes trogii. a, fleshy fruiting body in natural habitat; $b$, woody fruiting body with zonate upper surface; $c$, tubular layer of fruiting body; $d$, porous upper surface.
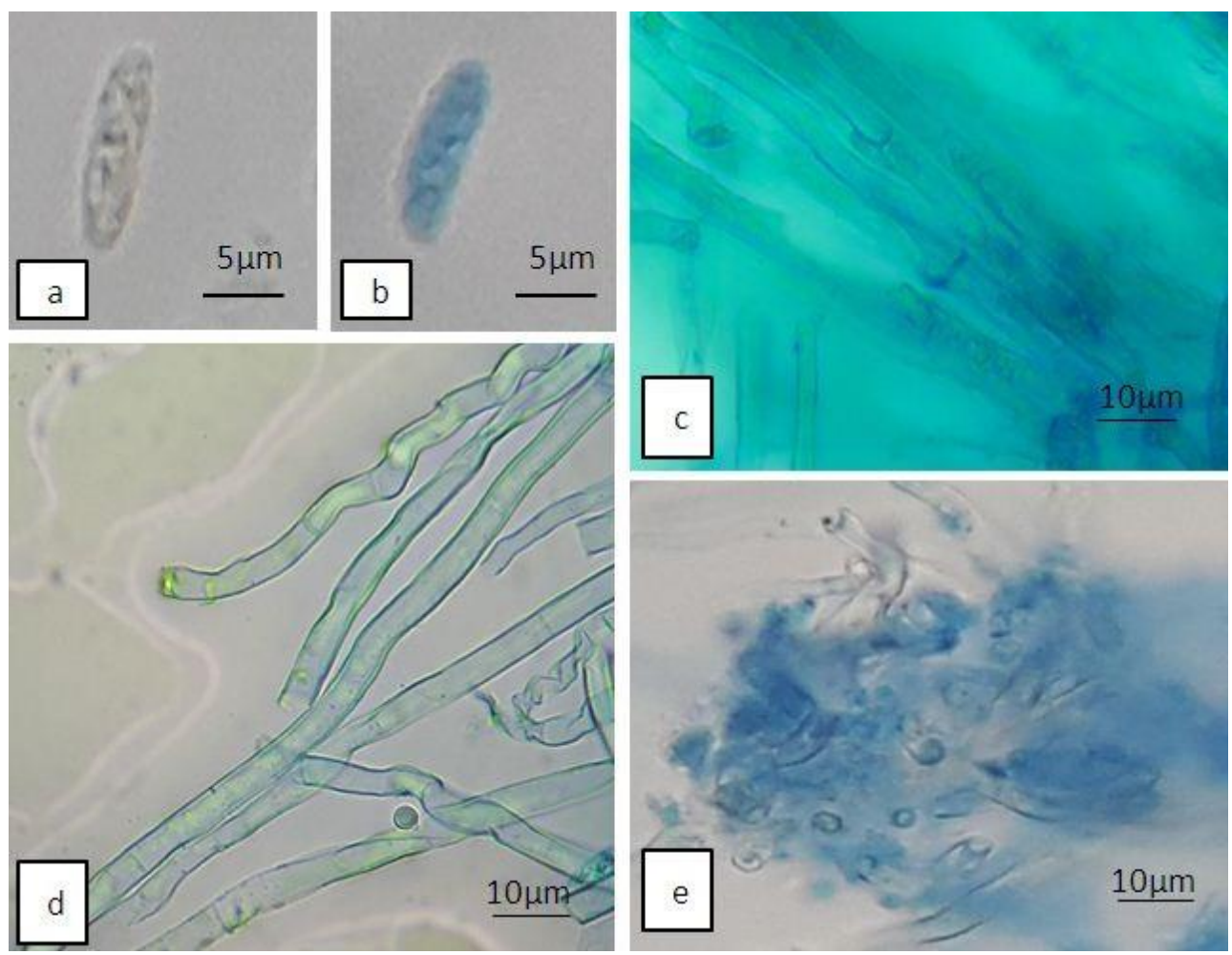

Figure 14. Trametes trogii. a, stained spore; $b$, unstained spore; $c$, generative hyphae with clamp connections; d, skeletal hyphae ; e, binding hyphae. 
from macrofungal point of view. Hence further survey of this group of fungi in this region is of great importance towards creating a checklist of macrofungi in Iraq.

\section{CONFLICT OF INTERESTS}

The authors have not declared any conflict of interests.

\section{REFERENCES}

Abou-Zeid A, Altalhi A (2006). Survey of some mushrooms in Al-Taif governorate of Saudi Arabia. World J. Agric. Sci. 2(1):1-5.

Adejumo T, Awosanya O (2005). Proximate and mineral composition of four edible mushroom species from South Western Nigeria. Afr. J. Biotechnol. 4(10):1084-1088.

Afyon A, Konuk M, Yagiz D, Helfer S (2005). A study of wood decaying macrofungi of western Black Sea Region, Turkey. Mycotaxon 93:319322.

Akata I, Uzu Y, Kaya A (2014). Macromycetes determined in Yomra (Trabzon) district. Turk. J. Bot. 38:999-101.

Amoopour M, Ghobad-Nejhad M, Khodaparast S (2016). New records of polypores from Iran, with a checklist of polypores for Gilan Province. Czech Mycol . 68:139-148.

Atila O, Kaya A (2008). Macromycetes of Sarı (Kayseri/Turkey) district. Biol. Divers. Conserv. 6(2):50-54.

Cimap $P$ (2005). Biodiversity of agarics from Nilgiri Biosphere Reserve, Western Ghats. Curr. Sci. 88:1890-1892.

De Román M, Boa E (2004). Collection, marketing and cultivation of edible fungi in Spain. Micol. Aplicada Int. 16:25-33.

De Silva DD, Rapior S, Sudarman E, Stadler M, Xu J, Alias SA, Hyde KD (2013). Bioactive metabolites from macrofungi: ethnopharmacology, biological activities and chemistry. Fungal Divers. 62(1):1-40.

Devi K, Shrivastava K (2016). Diversity of macrofungi in 'Jalukbari reserve forest'of Kamrup District, Assam. Adv. Appl. Sci. Res. 7(1):115-119.

Doğan HH, Öztürk C, Kaşık G, Aktaş S (2007). Macrofungi distribution of Mut province in Turkey. Pak. J. Bot. 38(1):293-308.

Dulay R, Arenas C , Kalaw P, Reyes G, Cabrera C (2014). Proximate composition and functionality of the culinary-medicinal tiger sawgill mushroom, Lentinus tigrinus (Higher basidiomycetes), from the Philippines. Int. J. Med. Mushrooms 16(1): 85-94.

Dulay R, Cabrera E, Kalaw S, Reyes R (2012). Optimal growth conditions for basidiospore germination and morphogenesis of Philippine wild strain of Lentinus tigrinus (Bull.) Fr. Mycosphere 3:926-933.

Fadavi S, Abbasi S (2015). A contribution to the identification of agaric fungi of Kermanshah, W Iran (2). Rostaniha 16:1-16.

Gargano ML, Saitta A, Zervakis GI, Venturella G (2011). Building the jigsaw puzzle of the critically endangered Pleurotus nebrodensis: historical collection sites and an emended description. Mycotaxon 115(1):107-114

Ghobad-Nejhad M, Kotiranta H (2008). The genus Inonotus sensu lato in Iran, with keys to Inocutis and Mensularia worldwide. Ann. Bot. Fenn. 45:465-476.

Ghobad-Nejhad M, Hallenberg N (2012). Checklist of Iranian non-gilled I non-gasteroid hymenomycetes (Agaricomycotina). Mycotaxon 119:494.

Groposo C, Loguercio C (2005). Contribution to the lignocellulolytic fungi (Basidiomycetes) of the Atlantic Rain Forest in Southern Brazil. Mycotaxon 92:103-106.

Güngör H, Alli H, Işiloğlu M (2013). Three new macrofungi records for Turkey. Turk. J. Bot. 37:411-413.

Güngör H, Solak MH, Alli H, Işiloğlu M, Kalmiş E (2015). New records for Turkey and contributions to the macrofungal diversity of Isparta Province. Turk. J. Bot. 39:867-877.
Justo A, Vizzini A, Minnis AM, Menolli N, Capelari M, Rodriguez O, Malysheva E, Contu M, Ghignone S, Hibbett DS (2011). Phylogeny of the Pluteaceae (Agaricales, Basidiomycota): taxonomy and character evolution. Fungal Biol. 115:1-20.

Karunarathnas SC, Yang ZL, Zhao RL, Vellinga EC, Bahkali A Chukeatirote E, Hyde KD (2011). Three new species of Lentinus from northern Thailand. Mycol. Prog. 10:389-398.

Kaya A (2015). Contributions to the macrofungal diversity of Atatürk Dam Lake basin. Turk. J. Bot. 39:162-172.

Kinge T, Egbe E, Tabi E, Nji T, Mih A (2013). The first checklist of macrofungi of mount Cameroon. Mycosphere 4:694-699.

Kobayashi T, Courtecuisse R (1993). Two new species of Inocybe from Japan. Mycotaxon 46:27-33.

Kuo M (2003). Shizophyllum commune. Retrieved from the Mushroom Expert. Com Web site: http://www.mushroomexpert.com/schizophyllum_commune.html.

Kuo M (2011). Psathyrella spadiceogrisea. Retrieved from the Mushroom Expert. Com Web site: http://www.mushroomexpert.com/ psathyrella spadiceogrisea.html.

Lahony SRA, Mohammad MK, Ali HH, AL-moussawi AA, AL-Rasul MSA (2013). Hawraman lowest zone, Kurdistan province north east of Iraq. Bull. Iraq Nat. Hist. Mus. 12:7-34.

Larsson E, Örstadius L (2008). Fourteen coprophilous species of Psathyrella identified in the Nordic countries using morphology and nuclear rDNA sequence data. Mycol Res. 112:1165-1185.

Laursen GA, Ammirati JF, Redhead SA (2013). Arctic and alpine mycology II (Vol. 34). Springer. Science \& Business Media.

Mueller GM, Schmit JP, Leacock PR, Buyck B, Cifuentes J, Desjardin $\mathrm{DE}$, Halling RE, Hjortstam $\mathrm{K}$, Iturriaga $\mathrm{T}$, Larsson $\mathrm{KH}$, Lodge DJ (2007). Global diversity and distribution of macrofungi. Biodivers. Conserv. 16(1):37-48.

Perini C, Lagana A, Salerni E, Barluzzi C, Dedominicis V (1999). Mycofloristic investigations in the geothermal area of Travale Radicondoli (Tuscany, Central Italy). Webbia 54:149-173.

Phillips R (2013). Mushrooms: A comprehensive guide to mushroom identification, Pan Macmillan.

Pidlich-Aigner H, Hausknecht A, Scheuer C (2001). Annotated list of macromycetes found in the greenhouses of the Botanic Garden of the Institute of Botany in Graz (Austria), 1998-2001. Fritschiana 32:49-61.

Razaq A, Shahzad S (2015). New record species of family Lintinaceae from Pakistan. FUUAST J. Biol. 5(1):17-19.

Redhead S (1997). Standardized Inventory Methodologies for Components of British Columbia's Biodiversity: Macrofungi. Resource Inventory Committee, Vancouver.

Ryvarden L, Gilbertson RL (1993). European polypores. Part 1. Synopsis Fungorum. 6:1-387.

Saba E (1991). Jordan wild mushrooms; their ecology, distribution, classification and toxicity. Thesis, Jordan University, Amman (Jordan). Department of Biological Sciences.

Senthilarasu G (2015). The lentinoid fungi (Lentinus and Panus ) from Western ghats, India. IMA fungus 6(1):119-128.

Sesli E, Denchev CM (2008). Checklists of the myxomycetes, larger ascomycetes, and larger basidiomycetes in Turkey. Mycotaxon 106:65-67.

Sharma SK, Atri NS (2015). The genus Lentinus (Basidiomycetes) from India - an annotated checklist. J. Threat. Taxa 7:7843-7848.

Solak M, Alli H, Işiloğlu M, Kalmiş E (2009). Some new records of Inocybe ( Fr. ) Fr. from Turkey. Turk. J. Bot. 33:65-69.

Vašutová M (2006). Preliminary checklist of the genus Psathyrella in the Czech Republic and Slovakia. Czech Mycol. 58(1-2):1-29.

Venturella G (2006). 2006. Pleurotus nebrodensis. The IUCN Red List of Threatened Species. 2006:e.T61597A12506882.

Venturella G, Zervakis G, Raimondo F (2002). Mycology in sustainable development: The case of Pleurotus nebrodensis from Sicily (Southern Italy). J. (Anon.). Protocols, A Guide to Methods and Applications.

Watanabe T (2010). Pictorial atlas of soil and seed fungi: morphologies of cultured fungi and key to species. CRC Press. 